\title{
SENIORS AS A RESEARCH GROUP IN THE EXPERIMENTAL MODEL
}

\author{
LUBA JAKUBOWSKA 1.jm@wp.pl \\ University of Wrocław \\ Poland
}

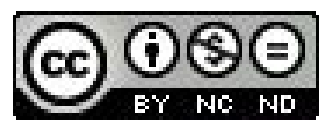

\begin{abstract}
The article focuses on the conduct of experimental research with seniors. I would like to present the limitations and the advantages of experimental research in the following fields: specifics of the method, specifics of the research group and competences of the researcher. Data gathered through interviews with persons engaged in the experiment with seniors will serve as illustration of the discussion. In the article I have emphasised the limitations, but only in order to demonstrate how attempts can be made at dealing with them. The advantages connected with the opportunities provided by experimental research are self-evident.
\end{abstract}

Key words: research process, experimental model, seniors, methodology, specifics of the method, specifics of the research, competences of the researcher

A leading Polish methodologist of psychological research claims that the extent to which the hypothesis formulated as part of a particular empirical academic discipline can be verified experimentally determines its maturity (Brzeziński 2007, p. 282). When considering the effectiveness of yet another research model Jerzy Brzeziński states that he agrees with the view that the experimental model should be used in scientific research whenever possible (Brzeziński 2007, p. 431). In the Psychologia Akademicka (en. Academic psychology) course book in the chapter concerned with scientific cognition the same author along with another methodologist of psychological research write that the branches of psychology in which the experiment providing results that are subject to complex and comprehensive quantitative analyses (mainly thanks to statistical analysis) constitutes the prevailing means of research have achieved rapid progress (Brzeziński, Zakrzewska 2010, p. 185). Even without enumerating the advantages of the experimental model as delineated by the abovementioned authors, as well as others, it may be proposed on the basis of the above statements that this method has a leading position in psychology. In the methodology of pedagogical research we witness no similar enthusiasm, although the authors themselves do not deny the effectiveness of the method. Though the opinions of the scholars of pedagogy vary, experiment may still be considered a method of pedagogical research (Pilch, Bauman 2011, p. 72). Starting with the turn of the 1950's and 1960's experimental methods in pedagogy regained popularity. Unfortunately, in the second half of the 1970's a regression that is still taking place today can be noticed. In certain academic research centres the methods face insurmountable dislike, along with quantitative research methods connected with them (Łobocki 2005, p. 106). Issues of an ethical nature related to the specifics of children as a research group may be some of 
the crucial problems connected with the pedagogy academics dislike about experimental research. When writing the present article I may have to face criticism arising from similar doubts, because seniors as research subjects may also appear to be subjects of specific character, i.e. of particular sensitivity. However, dismissing those doubts and proving the superiority of the experimental method over other means of conducting research are not my aim. It is my belief, nevertheless, that in connection with particular problems, with verification of the effectiveness of teaching methods constituting one of them, the importance of experiment is undeniable. Furthermore, awareness of the difficulties arising from the use of a research method should not be a discouraging impulse for researchers; to the contrary, the knowledge of them should lead to a better preparation of the research. I would like to present the limitations and the advantages of experimental research in the following fields: specifics of the method, specifics of the research group and competences of the researcher. Data gathered through interviews with persons engaged in the experiment with seniors will serve as illustration of the discussion.

\section{SPECIFICS OF THE METHOD - LIMITATIONS AND ADVANTAGES OF THE EXPERIMENTAL METHOD}

The specifics of the discussed method are determined by its three basic features - manipulation, control, and measurement. The features constitute the core of the definition of the experimental method:

The experimental model (E) is a model of verification of hypotheses related to dependence between a dependent variable (variables) and an independent variable (variables) which presupposes:

1. manipulation of at least one independent variable,

2. control of the other variables, the peripheral and distorting ones that the researcher considers important to the dependent variable, as well as

3. measurement of the changes of the dependent variable (variables) caused by the influence of the independent variable (variables) intended by the researcher (Brzeziński 2007, p. 286). The definition proposed by J. Brzeziński determines the way of conducting the experiment, with the simplified version of which presented as the following:

- Formulation of the research hypothesis

- Planning the research setting

- Selection of research subjects

- Selection among the population

- Division into groups

- Conducting the experiment

- Initial measurement

- Introducing the independent variable

- Final measurement

- Conclusions

- Supporting or rejecting the hypothesis

- Generalisation of the results. 
Hypothesis in pedagogical research may be related to e.g. the effectiveness of teaching methods or the effectiveness of the use of particular didactic means. Due to the perspective of lifelong development the problems of increasing the effectiveness of learning are no longer related to children and youth exclusively. The questions are also of utmost importance in research connected with seniors. When proposing a similar hypothesis in the case of seniors a researcher should take into account their specific learning abilities as well as the level of competences of using modern technology.

The independent variable that the researcher will introduce to the experimental group should, therefore, be carefully operationalized in order for it to combine knowledge of the experimental factor as well as the population to take part in the research. Control constitutes the essence of manipulation of the independent variable (Brzeziński 2008). Furthermore, the researcher should control all the variables important for Y (dependent variable - L.J.), and if it is impossible at least all the independent variables, and as many of the peripheral independent variables and the distorting independent variables as possible (Brzeziński 2008, p. 48). The independent variable important to $\mathrm{Y}$ is controlled when it is measured, i.e. its values for particular persons of the comparative groups are determined (Brzeziński 2008, p. 47) and when the researcher follows one of the two following procedures:

1. determination of the partial variance explained by the variable

2. equalization of the comparative groups in relation to the values or the range of values of independent variables (Brzeziński 2008, p. 47).

For example, gender may constitute such a peripheral variable. Taking into account that in organisations such as the Universities of the Third Age (U3A) most of the participants are women equalization in relation to gender would mean declining to select men for the research, which the seniors could consider as discrimination.

Selection of the study sample has a great influence on the control of peripheral variables (Francuz 2007, p. 90). In accordance with the rule of randomization the selection should be aleatory. This is particularly difficult to put into practise and it is hardly ever used, for such selection would require a precise definition of the population (Shaughnessy, Zechmeister \& Zechmeister 2002). In the case of seniors selection of the study sample will be determined first and foremost by the access to these persons (they might be e.g. the students of the Universities of the Third Age), the willingness of the subjects to participate in the experiment (which may be distorted by e.g. physical ailments that appear more often than in the case of young people). Each of these factors is decisive in whether it is possible to find persons willing to participate in the experiment throughout the entirety of its duration. With the unfeasibility of aleatory selection the employment of the second rule of randomization - random division of persons into the control and the experimental groups - becomes all the more important. The research may otherwise be subject to random mistakes arising from the occasional distorting independent variable (Brzeziński 2008). However, even with random division of persons into comparative groups (which will be discussed in the part connected with specifics of the group) certain problems may arise.

One of the most important factors when carrying out experimental measurement is that the composition of research subjects during pre-tests and post-tests be 
the same. If research subjects are selectively excluded from the experimental study sample and the control study sample the final study sample from which all the data is collected may be biased (Frankfort-Nachmias, Nachmias 2001, p. 124). It is, therefore, crucial that the research subjects do not quit. Yet another important issue is for people not to perceive their participation in the experiment as a personal challenge or actions that are to meet the expectations of the researcher "by all means".

Further difficulties may be encountered when making an attempt at generalization. If the persons taking part in the experiment are students of the U3A can we state that they represent the senior population? The objection that students of the U3A differ from other seniors due to their higher activity, competences, etc. may be raised. "The research subjects had at least basic knowledge of the use of computers, and that is why the lecturer could concentrate on implementing the curriculum rather teaching the basics of computer use. The fact that all the participants are students of the U3A resulted in their computer use competences and experience connected with computer games" (Researcher 3 ). Certainly, the actual level of differences between the students and "non-students" of the U3A may be determined at the point of comparative research.

\section{LIMITATIONS AND ADVANTAGES OF A RESEARCH GROUP. SENIORS AS SUBJECTS OF EXPERIMENTAL RESEARCH}

The specifics of a research group may influence numerous areas of the research, such as: research subject-researcher relations, voluntary character of participation in the research (e.g. decisions of the parents in the case of children or other persons who cannot make independent decisions due to various reasons), the level of dedication of the research subjects, etc. In the case of seniors the last factor appears to be particularly advantageous: " (...) if their dedication, meticulousness, and serious approach towards the subject matter are put to good use and the importance in which they hold certain details is respected the cooperation can be fruitful" (Researcher 1). "The participants were active, open, willing to cooperate and take active part in the classes; one could see that they have precise expectations of the classes and that they want to participate" (Researcher 2) .

However, while working with seniors (especially in the case of experiments requiring frequent meetings) the researcher should be prepared for the fact that many factors distorting the conducting of the experiment may be related to the very specifics of the research group. " (...) Typically for working with seniors. If someone is dedicated, it is to the fullest, if someone is defiant, it is to the fullest, too. Seniors treat the classes more seriously than regular students and are more dedicated as a group. On the other hand, they like to challenge the authority of the teacher and try to take control of the classes. They are not very good at organising themselves - too many people are active all at once and then they fail to follow the established rules anyway. They come to the classes much too early (e.g. 30 minutes) and in this way they try to force others to start earlier. Hardly ever do they inform the teacher of their problems, they like to discuss them behind the instructors back (e.g. by complaining to those in higher authority). They do not hide their affections and disaffections for 
other members of the group. They tend to miss classes due to health problems and family responsibilities" (Researcher 1 ). Similar difficulties are addressed by yet another researcher: "unreal expectations of the participants of the experiment who were unhappy with the fact the classes are not individual and that they only take place until February, quarrels between the seniors, lack of mutual understanding, demanding attitude, (...) lack of discipline of the seniors (individual expectations of the subjects and information discussed in class), initial dislike of the games and acquiring of new competences, the seniors (some of them) saw the games as pointless - they thought they would not allow them to learn anything (waste of time), conflicts between the students, unwillingness (of some of the seniors) to work at home - some of the participants only played the games during the classes" (Researcher 3).

Such features as "precise expectations" which are to be found both in the advantages of the group as well as the aspects connected with difficulties cannot be ignored. The research subjects should be clearly informed of the advantages resulting from participation in the experiment. The advantages can be addressed in the following questions:

1. What exactly will the research subjects receive?

2. In what way will they support the population they represent?

3. How will they support science?

4. How will they help the researcher?

The first question is related to the particular competences that the seniors can acquire thanks to participation in the research and the use of their potential, learning more about themselves, etc.

The second question is related to the advantages for the broader group that the research subjects can identify with - e.g. the use of new methods when teaching seniors.

The third question addresses the contribution of the research to science (its particular branch) that the verification or refutation of hypotheses may make.

The fourth question emphasises the importance of the correctly conducted research to the researchers themselves. Hereby the researcher ought to explain that his efforts and expenditures may all be wasted in case of a lack of cooperation and dedication on behalf of the research subjects.

The expected advantages along with the risk of "side effects" of the experiment should be presented "reasonably" (Frankfort-Nachmias, Nachmias 2001). The researcher should not exaggerate the advantages of the experiment only to gain favour with the participants. Presenting only the benefits and the "crucial importance of the research" in all the aspects may be perceived as unreliable and turn against the researcher. That is why the information ought to be precise, truthful and firmly based in the reality that they are related to.

Yet another problem that was expressed in the researchers' statements was that of the insubordination of seniors. Failure to solve this problem may even result in distortions so great that they might lead to the non-success of the entire research. In the previous part I discussed the importance of the random division into comparative groups in the context of the experimental model. The experimental group may be 
considered more attractive by the research subjects which may distort the experiment to a substantial degree, because the people who find themselves in the less desirable group may feel offended, try to compete, etc. (Brzeziński 2003). The random division may also be distorted by other factors: "the persons taking part in the experiment (after the random selection) were dissatisfied with the fact that they are not in one group with the people they were friends with and the seniors wanted to exchange the lots they drew and move between groups" (Researcher 3). Yet another issue connected with insubordination that could have decisive influence on the successfulness of the experiment is following the instructions during the activities that are subject to measurement. "The participants would tend to cheat during control tests, to help each other (even though they knew that they would not be graded and the results would have no influence in their participation in the classes) despite their declarations not to do so (...) Some people would choose a different strategy and they would ostentatiously refuse to answer the test questions. It proved possible to eliminate the problem through persuasion and regular reminding of the participants of the aims of the experiment and the rules of conducting it" (Researcher 1). As already mentioned by Researcher 1, these examples suggest that the research subjects might not follow the instructions because, among others, they have not been sufficiently informed of the specifics of the classes that they participate in. It is the role of the researcher to make it clear that these are not regular classes and following instructions is of crucial importance in conducting them properly. The doubts connected with participation in the particular activities, discomfort, etc. should be addressed in research subjects' questions to the researcher. Writing down a contract to be put up before each meeting with the research subjects could be helpful, as well.

\section{COMPETENCES OF THE RESEARCHER - PREPARATION FOR CONDUCTING EXPERIMENTAL RESEARCH WITH SENIORS}

Discussion of the importance of the researcher for the conducting of the explorative process appears to be present in the postmodernist (Miller 2003; Usher, Bryant, Johnston 2001) and critical (Bauman 2006; Pryszmont-Ciesielska 2010) paradigms. The questions related to how personal experiences and traits of the researcher modify the research process have been addressed first and foremost in publications on the subject of biographical (auto/biographical) research (Miller 2003; Urbaniak-Zając 2011; Jakubowska 2010; Golonka 2011 and others). These are qualitative research methods where reflection on the subject of biography is not only connected to life histories of the research subjects, but of the researcher, as well. In publications on quantitative research the issue of competences of the researcher is addressed mainly in the areas related to respecting ethical rules of conduct (Brzeziński, Toeplitz-Winiewska 2010; Frankfort-Nachmias, Nachmias 2001 and others). Yet another problem appearing in the context of qualitative research is that of impartiality, objectivity of the researcher, of discipline in following the method. The metaphor of the researcher as one fully participating in the research (Malewski 1997; Malewski 1998) that is a part of the interpretative paradigm could be analysed in the context of the limitations of the research in the posi- 
tivist paradigm, rather than advantages, as in the case of the former. Therefore, e.g. impersonating the prison administrator by Philip Zimbardo in his famous The Stanford Prison Experiment is considered a mistake of the researcher. Features of a good researcher vary depending on the academic orientation. Specifics of quantitative research do not allow the use of some of the quite good solutions proposed by the advocates of the qualitative research methods.

However, I believe that the discussion of the trajectory of the researcher's "self" taking place in the context of the qualitative methodology may be useful in all forms of research. In order to benefit from these concepts a quantitative researcher ought to limit the ideas of auto/biography (Miller 2003) and the trajectory of the researcher's "self" (Usher, Bryant, Johnston 2001) to the issues related first and foremost to the awareness of one's own competences.

Being impartial, being an external observer (Malewski 1997, Malewski 1998) should not make it impossible for the researcher (at least not always) to benefit from his own experiences. The experiments in social sciences are conducted with people, and the specifics of particular groups (e.g. children, seniors, students, etc.) require approaches of diverse character from the moment of the explanation of the instructions to elimination of the possible negative results of the experiment. The researchers conducting the experiment with seniors would emphasize the importance of their experiences gained throughout their former work with seniors for the experiment process: "As to working with seniors, my experience was substantial - I formerly conducted computer skills training courses for quite some time, so the specifics of this age group are known to me (...) The experience with working with seniors made my work much easier, I knew what to expect from this age group" (Researcher 1).

"I had the opportunity to teach computer skills in a few groups in the years 2011-2012. I cooperate with the U3A and I have the opportunity to observe the (specific) behaviours of seniors (...) I am writing a doctoral thesis on the subject of seniors, I constantly broaden my knowledge of this specific stage of life" (Researcher 3). These experiences - as the researcher emphasizes - turned out to be quite helpful: "The knowledge related to seniors and the experiences gained while working with people of advanced age in the U3A as well as other competences acquired while working as an instructor in educational centres were favourable in conducting the experiment" (Researcher 3).

Apart from the experiences connected with the specifics of the groups the experiences related to the specifics of the method are of crucial importance. Such experience may be gathered directly while conducting an experiment or assisting in conducting an experiment, or indirectly through the study of reference works on the subject of the experimental model - i.e. reading and watching accounts of experimental research, participation in classes and training courses related to such research. "As to the experiment - I had known a lot about it previously in theory, during the earlier classes I had to plan experiments, I had taken part in experiments as a subject and I conducted some simple biological experiments at home (on plants etc.). However, it was the first time that I conducted a social experiment. Experience in working with seniors made my work much easier; I knew what to expect of this age group. Nevertheless, the fact that I was conducting an experi- 
ment for the first time certainly made me quite stressed, as is the case with all first times" (Researcher 1). It seems to be a good solution for the beginner researchers to start as assistants (before conducting research independently) in experiments supervised by a more experienced scholar.

Interviews with the researchers elucidated yet another interesting aspect that ought to be taken into account. The problem is not new, since it appears in methodological publications and it is connected with researcher-research subject relations that can be influenced by the psychophysical features of the researcher as well as the research subjects. In the case of research conducted with seniors the age of the researcher may turn out to be such an important feature: "(...) disciplining seniors is not easy (...) (some of the seniors have) difficulties accepting younger people as teachers (...) treating younger people "lightly", problems that seniors have with meeting the requirements and expectations set by an instructor or teacher who could be their grandchild" (Researcher 3). It is of crucial importance, therefore, that the researcher be perceived through his competences that are presented while conducting the experiment; that is why the "young scientist" should take particular care to be well-prepared for each meeting with the research subjects. The researcher's attitude towards seniors could be valuable in shaping favourable relations, as well. Such "helpful features" are discussed by Researcher 3, among others: "positive attitude, understanding, patience". Asymmetry of relations arising from the age difference should not be an obstacle if the researcher is able to present his competences while at the same time showing his respect for the research subjects.

\section{RECAPITULATION}

The researcher should be prepared to face difficulties that may result from the specifics of the method as well as the specifics of the research group. This problem is not only related to research conducted with seniors. Each of the groups determined by characteristic features of a particular population is specific. Even conducting research in "the favourite" (the most popular) group consisting of university students is not without its limitations. The students of the Universities of the Third Age constitute such an "older generation of students". That is why one may have to face certain limitations (and advantages, as well!) similar to those that one may have when conducting research with university students as well as those arising from the age of the research subjects.

In the article I have emphasised the limitations, but only in order to demonstrate how attempts can be made at dealing with them. The advantages connected with the opportunities provided by experimental research are self-evident. In pedagogy they are, among others, the opportunity for a practical assessment of ideas, a source of inspiration in modernising didactic and educational work, a connection between the researcher and practical pedagogy (Łobocki 2007). Psychology scholars may, in turn, be interested in testing hypotheses on causes of behaviours and making decisions as to what influence and what programme may effectively change the behaviours (Shaughnessy, Zechmeister, Zechmeister 2002, p. 226). Furthermore, thanks to experiments the researcher does not have to wait to see the 
influence of a certain variable, so it is possible to learn quickly whether something is effective or not, which allows for saving time and expenditures through preceding each innovative programme with an experiment. In research with seniors we are far behind, since andragogy is a much younger branch than pedagogy, and the idea of lifelong learning has only recently gained wider social recognition and popularity. It is, therefore, important to work hard to catch up.

\section{BIBLIOGRAPHY}

Bauman T. (2006), Badacz jako krytyk, [in:] Kubinowski D., Nowak M. (eds.), Metodologia pedagogiki zorientowanej humanistycznie, Oficyna Wydawnicza Impuls, Kraków.

Brzeziński J. (2007), Metodologia badań psychologicznych, Wydawnictwo Naukowe PWN, Warszawa.

Brzeziński J. (2008), Badania eksperymentalne w psychologii i pedagogice, Wydawnictwo Naukowe Scholar, Warszawa.

Brzeziński J., Toeplitz-Winiewska M. (2010), Etyczne problemy działalności praktycznej, edukacyjnej i naukowej psychologa, [in:] Strelau J., Doliński D. (eds.), Psychologia Akademicka, Vol. I, WP, Gdańsk.

Brzeziński J., Zakrzewska M. (2010), Metodologia, podstawy metodologiczne $i$ statystyczne prowadzenia badań naukowych w psychologii, [in:] Strelau J., Doliński D. (eds.), Psychologia Akademicka, Vol I, GWP, Gdańsk.

Dubas E., Świtalski W. (eds.) (2011), Uczenie się z wtasnej biografii, Wydawnictwo Uniwersytetu Łódzkiego, Łódź.

Francuz P., Mackiewicz R. (2007), Liczby nie wiedza, skąd pochodza, przewodnik po metodologii i statystyce, Wydawnictwo Kul, Lublin.

Frankfort-Nachmias Ch., Nachmias D. (2001), Metody badawcze w naukach społecznych, Wydawnictwo Zysk i S-ka, Poznań.

Golonka J. (2011), "Uczenie się z biografii” - indywidualna koncepcja wykorzystania wywiadu biograficznego, [in:] Dubas E., Świtalski W. (eds.), Uczenie się z własnej biografii, Wydawnictwo Uniwersytetu Eódzkiego, Łódź.

Jakubowska-Malicka L. (2010), Trajektoria autobiografii badacza, „Teraźniejszość, Człowiek, Edukacja” $4(52)$.

Kubinowski D., Nowak M. (eds.) (2006), Metodologia pedagogiki zorientowanej humanistycznie, Oficyna Wydawnicza Impuls, Kraków.

Łobocki M. (2005), Metody i techniki badań pedagogicznych, Oficyna Wydawnicza Impuls, Kraków.

Łobocki M. (2007), Wprowadzenie do metodologii badan pedagogicznych, Oficyna Wydawnicza Impuls, Kraków.

Malewski M. (1997), Metody ilościowe i jakościowe w badaniach nad edukacja. Spór o metodologiczna komplementarność, „Kultura i Edukacja” 1-2.

Malewski M. (1998), Teorie andragogiczne. Metodologia teoretyczności dyscypliny naukowej, Wydawnictwo Uniwersytetu Wrocławskiego, Wrocław.

Miller N. (2003), Auto/biografia w badaniach nad edukacją i uczeniem się całożyciowym, „Teraźniejszość Człowiek Edukacja" 1 (21).

Pilch T., Bauman T. (2011), Zasady badań pedagogicznych, Strategie ilościowe i jakościowe, Wydawnictwo Akademickie Żak, Warszawa.

Pryszmont-Ciesielska M. (2010), Ukryty program edukacji akademickiej, Oficyna Wydawnicza Atut, Wrocław.

Shaughnessy, J. J., Zechmeister, E. B., Zechmeister J. S. (2002), Metody badawcze w psychologii, GWP, Gdańsk.

Strelau J., Doliński D. (eds.) (2010), Psychologia akademicka, Vol I, GWP, Gdańsk.

Urbaniak-Zając D. (2011), Biograficzna perspektywa badawcza, [in:] Dubas E., Świtalski W. (eds.), Uczenie się z własnej biografii, Wydawnictwo Uniwersytetu Łódzkiego, Łódź.

Usher R., Bryant I., Johnston R. (2001), Podmiot poznajacy w badaniach edukacyjnych (perspektywa postmodernistyczna), "Teraźniejszość Człowiek Edukacja” 2 (14). 